\title{
Demand for Imports and Components of Final Expenditure: An Empirical Study with Special Reference to the Korean Import Demand Function
}

\section{Il-Hyun Yoon ${ }^{1}$ H. R. Seddighi ${ }^{2}$}

'Division of Global Business Administration, Dongseo University, 47 Jurye-ro, Sasang-gu, Busan 47011 Korea. Email:ihyoon58@gdsu.dongseo.ac.kr Tel:82-51-320-2631

'Business School, University of Sunderland, St. Peter's Campus, St. Peters Way, Sunderland, Tyne and Wear SR6 ODD UK.

Email:hamid.seddighi@sunderland.ac.uk.Tel:44-191-515-3109

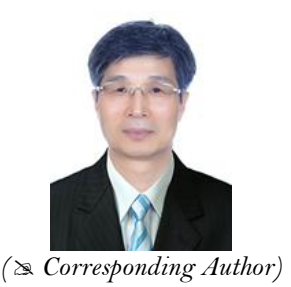

\section{Abstract}

This paper presents a detailed empirical investigation of Korea's demand for imports. In particular, our study provides fresh estimates of partial elasticities of demand for imports with respect to each key component of final expenditure including final consumption expenditure, and expenditure on capital formation. A Johansen multivariate co-integration analysis is employed on the post-global financial crisis quarterly macroeconomic data such as final consumption, gross fixed capital formation, exports and relative import prices for the sample period 2009-2018. In support of the empirical framework used in this study, we have found significant differences to exist between various long-run partial elasticities of demand for imports while import elasticity of demand with respect to expenditure on fixed capital formation is found to be negative. This latter result appears to imply that incremental increases in capital formation can provide an effective mechanism for reducing reliance of Korea on imports in the long run. According to the short-run forecasting model, we have found that the current period changes in the demand for imports are related only to the previous period changes in relative price of imports.

Keywords: Cointegration, Economic policies, Error correction model, Korea, Partial elasticities, Unit root.

JEL Classification: C32; F14.

Citation | Il-Hyun Yoon; H. R. Seddighi (2019). Demand for Imports and Components of Final Expenditure: An Empirical Study with Special Reference to the Korean Import Demand Function. Asian Journal of Economics and Empirical Research, 6(1): 52-58. History:

History:

ed. 7 November 2018

Revised: 21 December 2018

Accepted: 17 January 2019

Published: 11 April 2019

Licensed: This work is licensed under a Creative Commons

Attribution 3.0 License (cc) E E

Publisher: Asian Online Journal Publishing Group
Contribution/Acknowledgement: Both authors contributed to the conception and design of the study.

Funding: This study received no specific financial support.

Competing Interests: The authors declare that they have no conflict of interests.

Transparency: The authors confirm that the manuscript is an honest, accurate, and transparent account of the study was reported; that no vital features of the study have been omitted; and that any discrepancies from the study as planned have been explained.

Ethical: This study follows all ethical practices during writing.

\section{Contents}

1. Introduction

2. Modeling Framework and Data

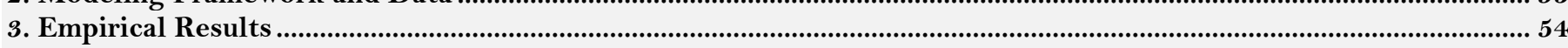

4. A Short-Run Error Correction Forecasting Model for Aggregate Imports ............................................................... 55

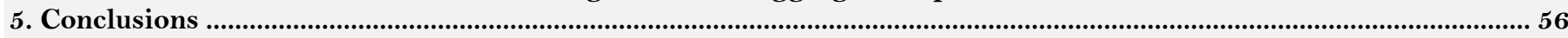

References 


\section{Introduction}

There have been a plethora of empirical studies over the past decades on estimation of aggregate import demand based on the national income and relative price of imports in various countries across the world, reflecting the significance of import for trade policies not just to researchers but also to policymakers.

Studies have been conducted on the basis of both multi-country comparison and country-specific investigation. For multi-country examinations, there are Asseery and Peel (1991) for five developed economies, BahmaniOskooee (1998) for six less developed nations, Sinha (2001) for five nations in Asia, Alias et al. (2001) for five ASEAN countries, and Matsubayashi and Hamori (2003) for G7 member countries. Examples of country-specific investigation, to name a few among many, include Salas (1982) for the Mexico, Doroodian et al. (1994) for Saudi Arabia, Abbott and Seddighi (1996) for the UK, Carone (1996) for the US, Sinha (1997) and Ahad et al. (2017) for Pakistan, Arize et al. (2000) for Thailand, Alias and Tang (2000) for Malaysia, Tang (2003a); Wang and Lee (2012); and Gozgor (2014) for China, and Arize and Walker (1992) and Tang (2003b;2006;2008a;2008b;2015) for Japan.

Several studies have also been done for import demand for Korea. Arize and Ndubizu (1992) based on Engle and Granger (1987) method, documented that there is cointegration among aggregate imports, GDP, relative import price and current account balance in Korea. Mah (1992) used annual data for the period of 1971-1988 with the ordinary least squares approach to find that the income is significant factor with the import price insignificant in estimation of Korean import demand. Mah (1993) reexamined import demand behavior for Korea by using quarterly data for period of 1971-1988 to produce different results with the income being less significant and the price being insignificant to the country's aggregate imports after 1981. Bahmani-Oskooee and Rhee (1997) analyzed quarterly data over the period from 1971 to 1988 to find that at least one cointegrating vector exists among imports, gross national product (GNP) and relative price of imports based on maximum-likelihood method by Johansen and Juselius (1990). Senhadji (1998) analyzed annual data for the period from 1960 to 1993 and found a long-run relationship among real imports, relative import prices and income in Korea. Bahmani-Oskooee (1998) found that there are two cointegrating vectors for Korea among imports, relative price of import, domestic income and exchange rate in the multi-country study for the less developed economies based on quarterly data of 19731990 .

Later, Min et al. (2002) examined Korean aggregate import demand with the annual data for the period from 1963 to 1998 to find that the major determinants of import in the long run are final consumption expenditure, import price and export demand with elasticities of 1.04, -0.6 and 0.49, respectively. More recently, Tang (2005) examined the long-run relationships of aggregate import demand behavior in Korea, using bounds test procedure with quarterly data from 1970 to 2002 to show evidence of a cointegrating relation which is consistent with earlier studies. Chang et al. (2005) also used the bounds test method to examine the Korea's aggregate import demand function for the period from 1980 to 2000 and found that imports, income and relative prices are cointegrated.

Almost all of the above studies on the estimation of aggregate import demand have used total domestic income (GDP) and relative import price on the assumption that long-run elasticity of import demand relating to each component of aggregate demand is the same, thus using a single regressor to represent aggregate demand in the import is function. However, if each component of final expenditure has different import content, the use of a single variable in the aggregate import demand function could cause aggregation bias, hence leading to incorrect estimates (see Gorman (1953); Theil (1954) and Stoker (1993) for more details). Furthermore, there is some evidence from the EU member countries which appear to suggest aggregate imports react differently to changes to each component of aggregate demand (see, for example, Eurostat (2010)). Accordingly, in this paper, we will distinguish between different categories of final expenditure in the import demand equation to investigate the response of aggregate imports to a change in expenditure in each one of final demand category. This type of disaggregation of final demand in the import function is consistent with the treatment of aggregate demand in a number of pioneering empirical studies which have found robust results on various elasticities of demand for imports (for example, Abbott and Seddighi (1996)). This study would follow Abbott and Seddighi's methodology to empirically examine Korea's aggregate import demand under the reformed economic paradigm currently in place in Korea.

The remainder of this paper is structured as follows. Section 2 discusses the model, data and methodology used. Section 3 reports the results of empirical analysis and implications. Section 4 presents additional analysis of the short-run error correction model before concluding the paper in Section 5.

\section{Modeling Framework and Data}

Based on economic theory, we have disaggregated aggregate expenditure into its key components in the demand for import function as follows:

$$
I M P T=f(F I N C O N, I N V T, E X P T, P R I C E)
$$

Where IMPT is demand for aggregate imports, FINCON is the final consumption expenditure, INVT is expenditure on investment goods measured by gross fixed capital formation and EXPT is the total amount of exports, all measured in constant prices. PRICE represents the relative price of imports to domestic prices $\left(\mathrm{P}_{\mathrm{M}} / \mathrm{P}_{\mathrm{D}}\right)$ measured by the ratio of import price deflator $\left(\mathrm{P}_{\mathrm{M}}\right)$ (defined as ratio of imports in current prices over imports in constant prices) by the index of domestic prices $\left(\mathrm{P}_{\mathrm{D}}\right)$ (measured by the GDP deflator). All variables are in natural logarithmic form. The data used in this study are quarterly from 2009:1 to 2018:4 obtained from Economic Statistical System (ECOS) of the Bank of Korea.

In order to test for the existence of the long-run relationship between demand for imports and variables specified by economic theory in the import demand function Equation 1, we have employed a multivariate cointegration analysis consisting of the following steps:

1. Using an ADF test to test for the order of integration of each variable.

2. Using co-integration tests, including Trace and Eigen-value tests, to investigate whether or not there exists a unique cointegrating vector linking variables specified in the import demand function. 
3. Determining the long-run relationships between variables identified in the import demand function, on the basis of steps 1 and 2 .

4. Deriving a short-run error correction forecasting model, using a general to specific methodology.

The results of the each step in this empirical investigation will be presented in the following sections.

\subsection{A Summary Characteristics of Data Used in the Empirical Investigation}

Table 1 shows the descriptive statistics of the variables used in this study. Normal distribution characteristics appear not to be present in the data series as it is indicated by the Jarque-Bera, Skewness and Kurtusis statistics. Most of the variables are shown as flat (platykurtic) with respect to the normal as the kurtosis is less than 3 . The skewness statistics are negative in most of variables, indicating a longer tail to the left than to the right side and the skewed distribution to the left.

\begin{tabular}{|c|c|c|c|c|c|}
\hline Variable & IMPT & FINCON & INVT & EXPT & PRICE \\
\hline Mean & 32.50766 & 33.03716 & 32.28471 & 32.6251 & -0.09238 \\
\hline Median & 32.53556 & 33.0377 & 32.25921 & 32.64229 & -0.05395 \\
\hline Maximum & 32.70107 & 33.17553 & 32.47589 & 32.78553 & 0.1715 \\
\hline Minimum & 32.18521 & 32.88508 & 32.10842 & 32.26074 & -0.404477 \\
\hline Std. Dev. & 0.128178 & 0.075547 & 0.104083 & 0.12173 & 0.169606 \\
\hline Skewness & -0.878776 & -0.001962 & 0.452384 & -1.246295 & -0.163357 \\
\hline Kurtosis & 3.044742 & 2.122575 & 1.990439 & 4.227326 & 1.640127 \\
\hline Jarque-Bera & 5.151655 & 1.283149 & 3.06303 & 12.86557 & 3.259992 \\
\hline Probability & 0.076091 & 0.526463 & 0.216208 & 0.001608 & 0.19593 \\
\hline Sum & 1300.306 & 1321.486 & 1291.388 & 1305.004 & -3.695208 \\
\hline Sum Sq. Dev. & 0.640755 & 0.222589 & 0.422501 & 0.577914 & 1.121877 \\
\hline Observations & 40 & 40 & 40 & 40 & 40 \\
\hline
\end{tabular}

\section{Empirical Results}

Table 2 displays the results of the ADF unit root tests at level and first difference series of each variable. The test results confirm that all series are stationary after first differencing.

\begin{tabular}{l|c|c|c|c}
\hline \multirow{2}{*}{ Variable } & \multicolumn{2}{|c}{ Level } & \multicolumn{2}{c}{ First Difference } \\
\cline { 2 - 5 } & ADF $\boldsymbol{t}$-statistic & $\boldsymbol{p}$-value & ADF $\boldsymbol{t}$-statistic & $\boldsymbol{p}$-value* \\
\hline IMPT & -2.2576 & 0.1904 & -7.4089 & 0 \\
\hline FINCON & -1.0660 & 0.7195 & -7.5529 & 0 \\
\hline INVT & -1.1394 & 0.6904 & -6.0760 & 0 \\
\hline EXPT & -3.4529 & 0.0149 & -11.8261 & 0 \\
\hline PRICE & -0.8443 & 0.7950 & -2.6966 & 0.0842 \\
\hline
\end{tabular}

In order to implement the Johansen's cointegration test (Johansen, 1988) the appropriate lag length is to be selected for the VAR. On the basis of the Schwarz information criterion (Schwarz, 1978) and Hannan-Quinn information criterion (Hannan and Quinn, 1979) the lag length was chosen to be one period. Under this specification, results of the trace test are shown in Table 3. These results appear to indicate that at most one cointegrating vector to exist with regard to variables specified in the model.

Table-3. Johansen cointegration test.

\begin{tabular}{c|c|c|c|c|c|c|c}
\hline \multicolumn{2}{c|}{ Null Hypothesis } & \multicolumn{3}{c}{ Trace } & \multicolumn{2}{c}{ Max-Eigen } \\
\hline No. of CE(s) & Eigenvalue & Statistic & 5\% Critical Value & Prob. $^{* *}$ & Statistic & 5 \% Critical Value & Prob. $* *$ \\
\hline None* & 0.5432 & 73.4387 & 69.8189 & 0.0250 & 0.5432 & 33.8769 \\
\hline At most 1 & 0.3798 & 43.6655 & 47.8561 & 0.1172 & 0.3798 & 27.5843 \\
\hline At most 2 & 0.3165 & 25.5122 & 29.7971 & 0.1439 & 0.3165 & 21.1316 & 0.143 \\
\hline At most 3 & 0.2430 & 11.0496 & 15.4947 & 0.2085 & 0.2430 & 14.2646 \\
\hline At most 4 & 0.0123 & 0.4712 & 3.8415 & 0.4924 & 0.0123 & 3.8415 & 0.1767 \\
\hline
\end{tabular}

Trace test indicates 1 cointegrating equation while Maximum-eigenvalue test indicates no cointegrating equation at the 0.05 level.

\begin{tabular}{c|c|c|c|c}
\hline \multicolumn{5}{c}{ Cointegrating Coefficients } \\
\hline IMPT & FINCON & INVT & EXPT & PRICE \\
\hline 49.1308 & -13.7890 & 13.5036 & -51.5676 & -11.6531 \\
\hline \multicolumn{7}{|c|}{ Normalized Cointegrating Coefficients (standard error in parentheses) } \\
\hline IMPT & FINCON & INVT & EXPT & PRICE \\
\hline 1 & -0.2807 & 0.2749 & -1.0496 & -0.2372 \\
\hline & $(-0.2203)$ & $(-0.1545)$ & $(0.0832)$ & $(-0.0553)$ \\
\hline
\end{tabular}

* denotes rejection of the hypothesis at the 0.05 level.

** MacKinnon et al. (1999) p-values.

The maximum eigenvalue test, which is considered to be more powerful than the trace test (Johansen and Juselius, 1990) is also presented. According to the results of both the trace and the maximum eigenvalue tests, there appears to be at most one statistically significant cointegrating vector with regard to the variables specified 
in the model. This cointegrating vector is shown in Table 3 with corresponding coefficient estimates, normalized on aggregate imports.

According to the above results, the long-run relationship among components specified in the model may be represented in Equation 2 as follows:

$$
I M P T=0.2807 \text { FINCON }-0.2749 I N V T+1.0496 E X P T+0.2372 \text { PRICE }
$$

The estimated coefficients represent estimates of long-run partial elasticities of demand for imports. According to these results, demand for imports with respect to final consumption expenditure are both inelastic with a value of 0.28 , approximately, implying that in the long run for each $1 \%$ increase in either of these two types of expenditure imports are likely to rise by only 0.28 of one percent. Similarly partial elasticity of demand with respect to to a change in exporting expenditure is found to be approximately 1.05, indicating to an elastic demand for imports with respect to this category of final expenditure. This category of final expenditure appears to dominate the response of demand for imports with respect to changes in final expenditure indicating that changes in demand for exports plays a key role in bring about changes in demand for imports in the long run, which appears to be consistent with the Korean's export -led growth policies. The partial elasticity of demand for imports with respect to a relative price change is found to be only +0.24 which indicates to an inelastic nature of demand for imports with respect to relative prices in the long run. The sign of this coefficient is expected to be negative, according to economic theory, however, this estimate could indicate that imports are considered to be a type of Giffen goods (Spiegel, 1994). This result implies that exchange rate policies which design to impact trade via changes in relative prices would be ineffective policy tool in reducing demand for imports in Korea in the long run.

With regard to the investment expenditure (measured by gross domestic fixed capital formation), according to the above results, elasticity of import with respect to this category of expenditure is found to be approximately 0.27 , which implies a fall of $0.27 \%$ in imports for every $1 \%$ rise in this category of expenditure. This is an unexpected but an interesting result, as one expects this partial elasticity to be positive and similar in magnitude to other estimated coefficients of final expenditure. However, there is clearly a difference between the responses of imports to changes in this category of final expenditure compared to those relating to other components of final demand. Furthermore, the estimated coefficient appears to indicate to the key role of investment expenditure as a policy tool in reducing dependency on imports in Korea in the long run. As more resources are allocated to fixed capital formation, this result seems to suggest that imports decrease as a result of growth in domestic productive capacity of the economy. Moreover, as imports appear to be price inelastic, increase in investment expenditure seems to be most effective policy tool for reducing imports in the long run.

\section{A Short-Run Error Correction Forecasting Model for Aggregate Imports}

Since variables employed in our modeling framework are confirmed to be non-stationary series and cointegrated, we can investigate the short-run behavior of the demand for imports via an error correction forecasting (ECM) model. To this end, the lagged residual error derived from the cointegrating vector was incorporated into a general error correction model as follows (Engle and Granger, 1987):

$$
\begin{aligned}
& \Delta I M P T_{t}=\alpha_{1}+\alpha_{2} U_{t-1}+\sum_{i=1}^{n} \alpha_{3 i} \Delta I M P T_{t-i}+\sum_{i=1}^{n} \alpha_{4 i} \Delta \operatorname{FINCON}_{t-i}+\sum_{i=1}^{n} \alpha_{5 i} \Delta I N V T_{t-i}+ \\
& \sum_{i=1}^{n} \alpha_{6 i} \Delta E X P T_{t-i}+\sum_{i=1}^{n} \alpha_{7 i} \Delta P R I C E_{t-i}+e_{t}
\end{aligned}
$$

Where $\alpha_{1}$ is the intercept, $\alpha_{2}$ is the coefficient of the error correction term, $\alpha_{3} \sim \alpha_{7 i}$ are the short-run coefficients of independent variables and $e_{t}$ is the white noise error term. $U_{t-1}$ is one period lag residual of the long-run model expressed as Equation 2, also known as the error correction term. Equation 3 represents that changes in the import demand are a function of the level of disequiribrium in the cointegrating relationship represented by the error correction term along with changes in independent variables. The $U_{t-1}$ guides each variable to restore the equilibrium relation, i.e., to correct disequilibrium.

The coefficient $\alpha_{2}$ measures at what rate it correct the previous period disequilibrium of the system, i.e., the speed of the adjustment towards the long-run equilibrium relationship. This general model was estimated by using a general to specific methodology, and the results of the vector error correction estimation are shown in Table 4 . The appropriate number of lags was set as one period in accordance with the Schwarz information criterion (Schwarz, 1978) and Hannan-Quinn information criterion (Hannan and Quinn, 1979). The top panel illustrates the results from the first step Johansen procedure. The bottom panel shows the coefficients of the error correction term, which is denoted CointEq 1, and other independent variables estimated by Equation 3.

Table-4. Vector error correction estimates.

\begin{tabular}{c|c|c|c|c|c}
\hline \multicolumn{7}{c}{ Cointegrating Eqn } \\
\hline IMPT(-1) & FINCON(-1) & INVT(-1) & EXPT(-1) & PRICE(-1) & C \\
\hline 1 & -0.2807 & 0.2749 & -1.0496 & -0.2372 & 2.1159 \\
\hline & $(-0.2203)$ & $(-0.1545)$ & $(-0.0832)$ & $(-0.0553)$ & \\
\hline & {$[-1.2742]$} & {$[1.7794]$} & {$[-12.6187]$} & {$[-4.2909]$} & \\
\hline
\end{tabular}

Standard errors in ( ) \& t-statistics in []

\begin{tabular}{c|c|c|c|c|c|c}
\hline \multicolumn{2}{l}{ Error Correction: Dependent Variable $=\Delta$ IMPT } \\
\hline CointEq1 & $\Delta$ IMPT(-1) & $\Delta$ FINCON(-1) & $\Delta$ INVT(-1) & $\Delta$ EXPT(-1) & $\Delta$ PRICE(-1) & $\boldsymbol{\alpha}_{\mathbf{1}}$ \\
\hline 0.3150 & -0.3514 & -0.4408 & 0.4960 & -0.1688 & 0.7283 & 0.0189 \\
\hline
\end{tabular}

Source: Outcome from Eviews 7 . 
Table 5, in addition, reports the results of the significance test of each variable including its standard error and t-statistic. The test results implies that there is no short-run causality running from private consumption, investment expenditure and government spending to import demand while exports and relative price of imports have short-run impact. In order to measure goodness-of-fit of the model, the result of the F-test for the overall significance of the model is presented, which is assumed to be satisfactory.

Given the above results, the short-run behavior of Korean aggregate imports may be presented by a simplified Equation 4 as follows:

$$
\Delta I M P T_{t}=+0.7283 \Delta P R I C E_{t-1}-0.0189 \mathrm{ECM}
$$

Where the ECM is an error correction term. According to this short-run forecasting model, the current period changes in the demand for imports are related to the previous period changes in relative price of imports, and an ECM term. This result may be taken to imply that exchange rates policies which directly work through relative prices could provide an effective policy tool for targeting a desired change in demand for imports in the short run.

\begin{tabular}{c|c|c|c|c}
\hline \multicolumn{7}{|c}{ Table-5. Error correction model estimates. } & t-Statistic & Prob. \\
\hline Variable & Coefficient & Std. Error & 0.6981 & 0.4903 \\
\hline$\alpha_{2}$ & 0.3150 & 0.4512 & -0.9887 & 0.3305 \\
\hline$\alpha_{31}$ & -0.3514 & 0.3554 & -0.2325 & 0.8177 \\
\hline$\alpha_{41}$ & -0.4408 & 1.8958 & 1.0253 & 0.3131 \\
\hline$\alpha_{51}$ & 0.4960 & 0.4838 & -0.5908 & 0.559 \\
\hline$\alpha_{61}$ & -0.1688 & 0.2857 & 3.0771 & 0.0043 \\
\hline$\alpha_{71}$ & $0.7283^{*} *$ & 0.2367 & 1.1632 & 0.2536 \\
\hline$\alpha_{1}$ & 0.0189 & 0.0162 & & \\
\hline F-statistic & & & &
\end{tabular}

F-statistic 3.4560.

Prob(F-statistic) 0.0099

Note: *** indicate significance at the $5 \%$.

Table 6 and Table 7 also confirms that the dynamic error correction model estimated in this study has neither serial correlation nor heteroskedasticity, as test results of Breusch-Godfrey test and Breusch-Pagan-Godfrey test for residuals shows that null hypothesis of no autocorrelation and no heteroskedasticity cannot be rejected as $p$ value is 0.0544 and 0.2588 , respectively.

\begin{tabular}{c|c|c|c}
\hline \multicolumn{5}{c}{ Table-6. Autocorrelation test. } \\
\hline \multicolumn{4}{c}{ Breusch-Godfrey Test: } \\
\hline F-statistic & 3.2369 & Prob. F(1,30) & 0.0821 \\
\hline Obs*R-squared & 3.7001 & Prob. Chi-Square(1) & 0.0544 \\
\hline & & & \\
\hline
\end{tabular}

Source: Outcome from Eviews 7.

Table-7. Heteroskedasticity test.

\begin{tabular}{c|c|c|c}
\hline \multicolumn{5}{c}{ Table-7. Heteroskedasticity test. } \\
\hline \multicolumn{4}{|c}{ Breusch-Pagan-Godfrey } \\
\hline F-statistic & 1.3088 & Prob. F $(10,27)$ & 0.2752 \\
\hline Obs*R-squared & 12.4062 & Prob. Chi-Square(10) & 0.2588 \\
\hline Source: Outcome from Eviews 7.
\end{tabular}

Figure 1 illustrates the result of the diagnostic tests which indicates that the short-run model appears to be well behaved with a white noise error term, suggesting that the model tracks the data well.

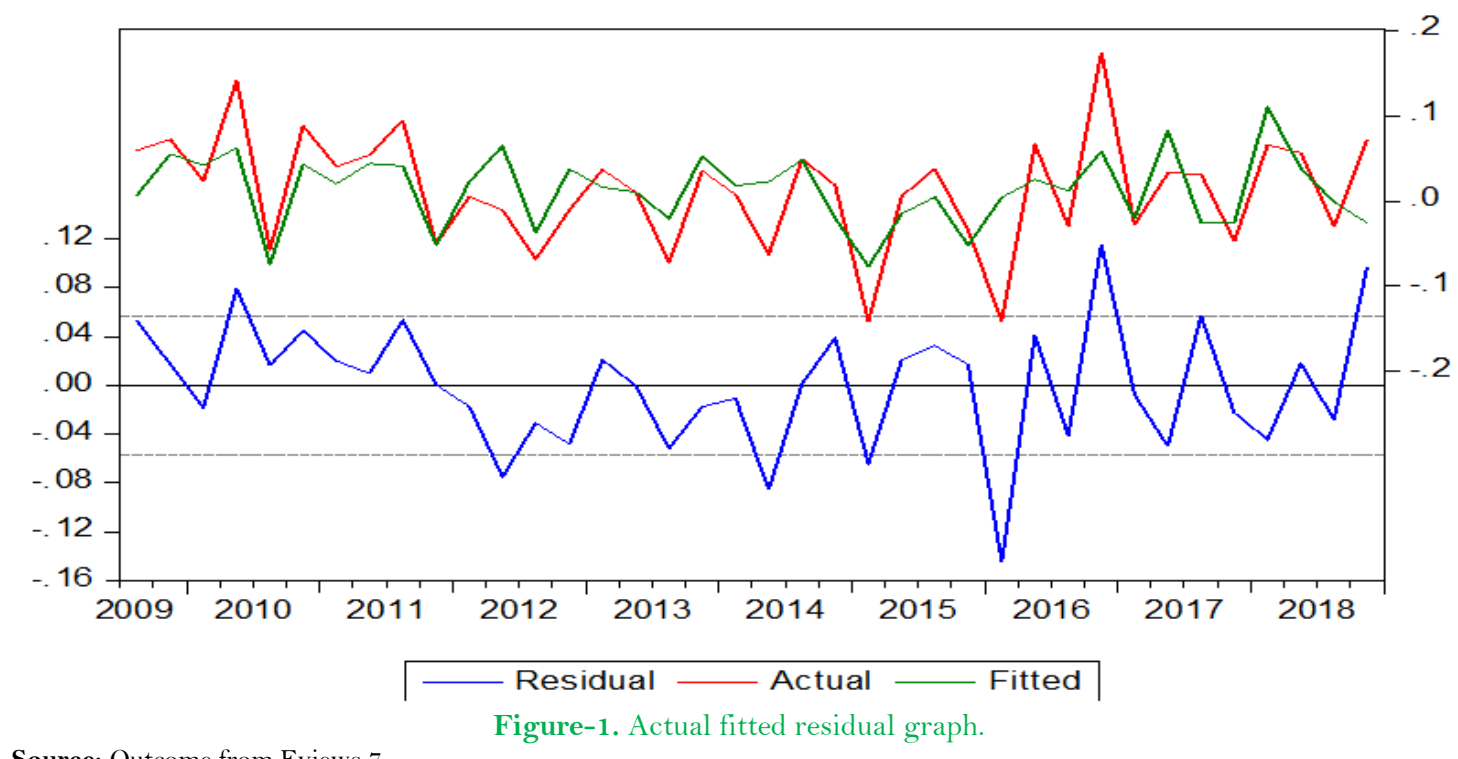

\section{Conclusions}

This study was motivated by the need to provide a rigorous examination of Korean import demand function in order to add to current debate on maintaining a positive balance of trade in the long run in this country. To this end, in this paper, we used the post-global financial crisis data to investigate the country's import demand under the reformed economic regime to avoid structural breaks in the time series data in the wake of the global financial crisis which broke out in 2007-8. To allow for different impact of each component of final expenditure on aggregate 
imports, in this study, we disaggregated final demand into final consumption expenditure, investment expenditure, and expenditure on exports. Within this framework, a multivariate co-integration analysis was then carried out to examine the long-run behavior of the Korean import demand function.

The empirical findings suggest that a long-run relationship is existent among aggregate imports, final expenditure components and relative price of imports. Furthermore, significant differences are found to exist among the long-run partial elasticities of imports as regards different macro components of final expenditure. Particularly, while partial elasticities with respect to final consumption and exports all appear to be positive, imports seems to respond negatively to changes in investment expenditure, implying that an increase in gross capital formation could result in a reduction in demand for imports in the long run. With regard to the relative import prices, our results appear to indicate to a insignificant influence on the aggregate imports in Korea in the long run. However, an error correction model designed for predicting the short-term variability shows that changes in relative import prices have a significant impact on changes in aggregate demand for imports in the short run.

These findings appear to have significant implications for policy makers in Korea in their quest to improve the country's trade balances in the long term. Particularly, exchange rate policies that have a direct influence on import prices are found to have little long-term effect on Korea's import demand, but might be used to bring a desired change in demand for imports in the short run. Furthermore, policies targeted to increase gross capital formation could play a key role in reducing imports in the long run, leading to further enhancement in the balance of trade in Korea.

\section{References}

Abbott, A.J. and H.R. Seddighi, 1996. Aggregate imports and expenditure components in the UK: An empirical analysis. Applied Economics, 28(9): 1119-1125.Available at: https://doi.org/10.1080/000368496327967.

Ahad, M., T. Afza and M. Shahbaz, 2017. Financial development and estimation of import demand function in Pakistan: Evidence from combined cointegration and causality tests. Global Business Review, 18(1): 118-131.Available at: https://doi.org/10.1177/0972150916666909.

Alias, M.H. and C.T. Tang, 2000. Aggregate imports and expenditure components in Malaysia. ASEAN Economic Bulletin, 17(3): 257257.Available at: https://doi.org/10.1355/ae17-3b.

Alias, M.H., T.C. Tang and J. Othman, 2001. Aggregate import demand and expenditure components in five ASEAN countries: An empirical study. Malaysia Economic Journal, 35(2001): 37-60.

Arize, A., P. Chooekawong and V. Prasanpanich, 2000. Foreign trade behavior in Thailand: Stable or unstable? The American Economist, 44(2): 36-45.Available at: https://doi.org/10.1177/056943450004400204.

Arize, A.C. and G. Ndubizu, 1992. Cointegration, error correction representation and the import demand function with implications in international finance and accounting research. Review of Quantitative Finance and Accounting, 2(4): 359-376.Available at: https://doi.org/10.1007/bfoo939017.

Arize, A.C. and J. Walker, 1992. A reexamination of Japan's aggregate import demand function: An application of the Engle and Granger two-step procedure. International Economic Journal, 6(2): 41-55.Available at: https://doi.org/10.1080/10168739200000010.

Asseery, A. and D.A. Peel, 1991. The effects of exchange rate volatility on exports: Some new estimates. Economics Letters, $37(2)$ : 173177.Available at: https://doi.org/10.1016/0165-1765(91)90127-7.

Bahmani-Oskooee, M., 1998. Cointegration approach to estimate the long-run trade elasticities in LDCs. International Economic Journal, 12(3): 89-96.Available at: https://doi.org/10.1080/10168739800080024.

Bahmani-Oskooee, M. and H.-J. Rhee, 1997. Structural change in import demand behavior, the Korean experience: A reexamination. Journal of Policy Modeling, 19(2): 187-193.Available at: https://doi.org/10.1016/0161-8938(95)00146-8.

Carone, G., 1996. Modeling the US demand for imports through cointegration and error correction. Journal of Policy Modeling, 18(1): 148.Available at: https://doi.org/10.1016/0161-8938(95)00058-5.

Chang, T.Y., H. Ho and C.J. Huang, 2005. A reexamination of South Korea's aggregate import demand function: The bounds test analysis. Journal of Economic Development, 30(1): 119-128.

Doroodian, K., R.K. Koshal and S. Al-Muhanna, 1994. An examination of the traditional aggregate import demand function for Saudi Arabia. Applied Economics, 26(9): 909-915.Available at: https://doi.org/10.1080/00036849400000052.

Engle, R.F. and C. Granger, 1987. Co-integration and error correction: Representation, estimation, and testing. Econometrica, 55(2): 251276.Available at: https://doi.org/10.2307/1913236.

Eurostat, 2010. European statistics. Available from http://ec.europa.eu/eurostat/.

Gorman, W.M., 1953. Community preference fields. Econometrica, 21(1): 63-80.Available at: https://doi.org/10.2307/1906943.

Gozgor, G., 2014. Aggregated and disaggregated import demand in China: An empirical study. Economic Modelling, 43: 1-8.Available at: https://doi.org/10.1016/j.econmod.2014.07.033.

Hannan, E.J. and B.G. Quinn, 1979. The determination of the order of an autoregression. Journal of the Royal Statistical Society: Series B (Methodological), 41(2): 190-195.Available at: https://doi.org/10.1111/j.2517-6161.1979.tbo1072.x.

Johansen, S., 1988. Statistical analysis of cointegration vectors. Journal of Economic Dynamics and Control, 12(2-3): 231-254.Available at: https://doi.org/10.1016/0165-1889(88)90041-3.

Johansen, S. and K. Juselius, 1990. Maximum likelihood estimation and inference on cointegration-with applications to the demand for money. Oxford Bulletin of Economics and statistics, 52(2): 169-210.Available at: https://doi.org/10.1111/j.14680084.1990.mp52002003.x.

MacKinnon, J.G., 1996. Numerical distribution functions for unit root and cointegration tests. Journal of Applied Econometrics, 11(6): 601618.Available at: https://doi.org/10.1002/(sici)1099-1255(199611)1 1:6<60 1::aid-jae41 7>3.0.co;2-t.

MacKinnon, J.G., A.A. Haug and L. Michelis, 1999. Numerical distribution functions of likelihood ratio tests for cointegration. Journal of Applied Econometrics, 14(5): 563-577.Available at: https://doi.org/10.1002/(sici)1099-1255(199909/10)14:5<563::aidjae530>3.3.co;2-i.

Mah, J.S., 1992. On the behavior of import demand of Korea. Asian Economic Journal, 6(2): 115-119.Available at: https://doi.org/10.1111/j.1467-8381.1992.tbo0085.x.

Mah, J.S., 1993. Structural change in import demand behavior: The Korean experience. Journal of Policy Modeling, 15(2): 223-227.Available at: https://doi.org/10.1016/0161-8938(93)90017-k.

Matsubayashi, Y. and S. Hamori, 2003. Some international evidence on the stability of aggregate import demand function. Applied Economics, 35(13): 1497-1504.Available at: https://doi.org/10.1080/0003684032000095965.

Min, B.S., M.H. Alias and T.C. Tang, 2002. An analysis of South Koreas import demand. Jornual of Asia-Pacific Affairs, 4(1): 1-16.

Salas, J., 1982. Estimation of the structure and elasticities of Mexican imports in the period 1961-1979. Journal of Development Economics, 10(3): 297-311.Available at: https://doi.org/10.1016/0304-3878(82)90032-3.

Schwarz, G., 1978. Estimating thedimension of a model. Annals of Statistics, 6(2): 461-464.

Senhadji, A., 1998. Time-series estimation of structural import demand equations: A cross-country analysis. Staff Papers, 45(2): 236268.Available at: https://doi.org/10.2307/3867390.

Sinha, D., 1997. An aggregate import demand function for Pakistan. Atlantic Economic Journal, 25: 114-114.Available at: https://doi.org/10.1007/bfo2298482 
Sinha, D., 2001. A note on trade elasticities in Asian countries. The International Trade Journal, 15(2): 221-237.Available at: https://doi.org/10.1080/088539001316901042.

Spiegel, U., 1994. The case of a giffen good. The Journal of Economic Education, 25(2): 137-147.Available at: https://doi.org/10.1080/00220485.1994.10844823.

Stoker, T.M., 1993. Empirical approaches to the problem of aggregation over individuals. Journal of Economic Literature, 31 (4): 1827-1874.

Tang, T.C., 2003a. An empirical analysis of China's aggregate import demand function. China Economic Review, 14(2): 142-163.Available at: https://doi.org/10.1016/s1043-951x(03)0002 1-x.

Tang, T.C., 2003b. Cointegration analysis of japanese import demand: Revisited. Applied Economics Letters, 10(14): 905-908.Available at: https://doi.org/10.1080/1350485032000164026.

Tang, T.C., 2006. Cointegration analysis of Japan's aggregate import demand function: Does data frequency matter? Labuan Bulletin of International Business and Finance, 4: 19-42.

Tang, T.C., 2008a. The demand for imports in Japan: A review article. International Journal of Business and Society, 9(1): 53-76.

Tang, T.C., 2008b. Aggregate import demand function for Japan: A cointegration reinvestigation. Global Economic Review, 37(3): 363377.Available at: https://doi.org/10.1080/12265080802273331.

Tang, T.C., 2005. Revisiting South Korea's import demand behavior: A cointegration analysis. Asian Economic Journal, 19(1): 2950.Available at: https://doi.org/10.1111/j.1467-8381.2005.00203.x.

Theil, H., 1954. Linear aggregation of economic relations. Amsterdam: North-Holland Publishing Co.

Wang, Y.-H. and J.-D. Lee, 2012. Estimating the import demand function for China. Economic Modelling, 29(6): 2591-2596.Available at: https://doi.org/10.1016/j.econmod.2012.08.002. 